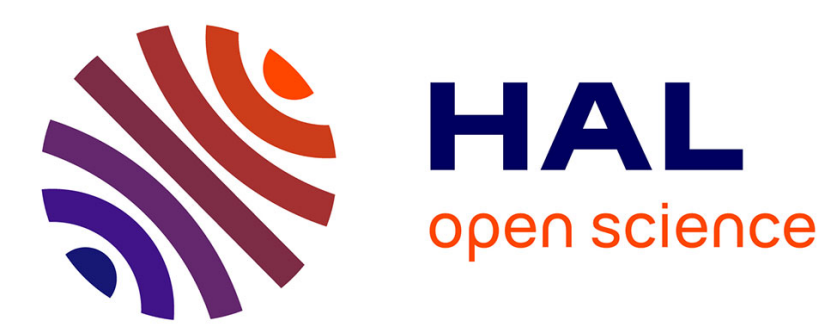

\title{
Toward conditions favourable to mobility of trace elements in soils.
}

Ary Bruand

\section{To cite this version:}

Ary Bruand. Toward conditions favourable to mobility of trace elements in soils.. Comptes Rendus Géoscience, 2005, 337, pp.549-550. 10.1016/j.crte.2005.02.004 . hal-00023345

\section{HAL Id: hal-00023345 \\ https://hal-insu.archives-ouvertes.fr/hal-00023345}

Submitted on 22 May 2006

HAL is a multi-disciplinary open access archive for the deposit and dissemination of scientific research documents, whether they are published or not. The documents may come from teaching and research institutions in France or abroad, or from public or private research centers.
L'archive ouverte pluridisciplinaire HAL, est destinée au dépôt et à la diffusion de documents scientifiques de niveau recherche, publiés ou non, émanant des établissements d'enseignement et de recherche français ou étrangers, des laboratoires publics ou privés. 


\title{
Toward conditions favourable to mobility of trace elements in soils
}

\author{
Ary Bruand
}

Institut des sciences de la Terre d'Orléans (ISTO), UMR 6113 CNRS-UO, université d'Orléans, Géosciences, BP 6759, 45067 Orléans cedex 2, France

\section{Introduction}

The mobility of trace elements in soils is often discussed because of consequences for their bioavailability and thus their potential ecological toxicity. Numerous studies showed that oxides and oxi-hydroxides could be an important sink for trace elements [1] and [2]. In many soils, trace elements tend to accumulate in oxides and oxihydroxides that act as scavengers [7], [9] and [10]. Indeed, as a recent example, extraction for As speciation in contaminated soils showed that As originating from irrigation was partly retained by Fe-oxi-hydroxides [3]. Other experiments also showed that adding Fe-bearing compounds to contaminated soils reduces As mobility, but increases $\mathrm{Pb}$ and $\mathrm{Cd}$ mobility [8], thus indicating that further investigations are required to elucidate trace-element mobility in soils. However, soil oxides and oxi-hydroxides play a significant role in controlling trace element mobility and new conditions leading to dissolution of oxides and oxi-hydroxides should be carefully considered.

\section{Effect of temporary high water content on iron- reducing bacterial activity}

If chemical dissolution of oxides and oxi-hydroxides can be recorded as being a consequence of a change in the redox potential alone caused by reductive conditions [4] and [5], microbial activity often plays also a significant role in the dissolution processes when easily biodegradable organic compounds are available. Thus, with batch experiments using samples collected in the topsoil horizon of a New Caledonia Ferralsol, Quantin et al. [11] and [12] showed that bacterial dissolution of Fe and Mn oxides occurs under anaerobic conditions and increases with the amount of glucose that was added to the samples.

These results were recorded for water-saturated soil samples, but a recent study showed that water soil saturation was not necessary for iron dissolution in a Ferralsol from Cameroon and a Gleysol from France [13]. This study showed that reductiondissolution of ferric iron was not directly correlated to the rates of anaerobic mineralization. Thus, water saturation of the samples was not, as often considered, a prerequisite for significant iron-reducing bacterial activity. This would indicate that in natural environments, bacterial dissolution of oxides and oxi-hydroxides does not require waterlogging. 


\section{A significant variation in trace-elements mobility}

Among consequences of bacterial reduction and dissolution of oxide and oxihydroxides, trace elements associated with them are also released. Dissolved $\mathrm{Mn}$ oxides were thus shown as being a major source of easily mobilisable Co and $\mathrm{Ni}$ in New Caledonia Ferralsols because of microbial activity under reducing conditions [11]. If, as shown by Stemmler et al. [13], microbial reduction of Fe oxides occurs at high soil water content but does not require soil water saturation, then release of trace elements associated to oxides and oxi-hydroxides can occur in soils for a larger range of conditions than those leading to waterlogging.

\section{Conclusion}

These new results show clearly that in the absence of waterlogging, increasing the occurrence of high water contents, might be enough to deeply change trace-element mobility in soils. This might happen in newly intensively irrigated soils. In the long term, among potential impacts that are discussed as consequences of climate change, an increase in precipitation is often considered in many areas [6]. This should also result in an increase in the occurrence and duration of high water contents in soils. In these different situations, increasing occurrence of high water contents will lead to new conditions that are favourable to mobility of trace elements. Thus, toxic trace elements immobilised in oxides and oxi-hydroxides should be released, with dramatic consequences for the surface water quality.

\section{References}

[1] H.B. Bradl, Adsorption of heavy metal ions on soils and soil constituents, J. Colloid Interface Sci. 277 (2004), pp. 1-18.

[2] R.M. Cornell and U. Schwertmann, The Iron Oxides: Structure, Properties, Reactions, Occurrences and Uses, John Wiley \& Son Ltd (2003) 703 p.

[3] S. Cornu, D. Montagne and P. Conil, Comparaison d'extractions séquentielles et cinétiques pour la spéciation de As dans des sols sableux contaminés, $C$. $R$. Geoscience 336 (2004), pp. 1007-1015.

[4] M. Davranche and J.-C. Bollinger, Release of metals from oxi-hydroxides under reductive conditions: Effect of metal/solid interactions, J. Colloid Interface Sci. 232 (2000), pp. 165-173.

[5] M. Davranche and J.-C. Bollinger, Heavy metals desorption from synthesized and natural iron manganese oxi-hydroxides: Effect of reductive conditions, J. Colloid Interface Sci. 227 (2000), pp. 531-559.

[6] K. Eckhardt and U. Ulbrich, Potential impacts of climate change on groundwater recharge and streamflow in a central European low mountain range, J. Hydrol. 284 (2003), pp. 244-252. 
[7] J.-M. Génin, P. Refait, G. Bourrié, M. Abdelmoula and F. Trolard, Structure and stability of the $\mathrm{Fe}(\mathrm{II})-\mathrm{Fe}(\mathrm{III})$ green rust 'fougerite' mineral and its potential for reducing pollutants in soil solutions, Appl. Geochem. 16 (2001), pp. 559-570.

[8] W. Hartley, R. Edwards and N.W. Lepp, Arsenic and heavy metal mobility in iron oxide-amended contaminated soils as evaluated by short- and long-term leaching tests, Environ. Pollut. 131 (2004), pp. 495-504.

[9] C. Latrille, F. Elsass, F. van Oort and L. Denaix, Physical speciation of trace elements in $\mathrm{Fe} \_\mathrm{Mn}$ concretions from a rendzic lithosol developed on Sinemurian limestones (France), Geoderma 100 (2001), pp. 127-146.

[10] A. Neaman, F. Mouélé, F. Trolard and G. Bourrié, Improved method for selective dissolution of Mn oxides: application for studying trace element association, Appl. Geochem. 19 (2004), pp. 973-979.

[11] C. Quantin, T. Becquer and J. Berthelin, Mn oxide: a major source of easily mobilisable $\mathrm{Co}$ and $\mathrm{Ni}$ under reducing conditions in New Caledonia Ferralsols, C. R. Geoscience 334 (2002), pp. 273-278.

[12] C. Quantin, T. Becquer, J.-H. Rouiller and J. Berthelin, Oxide weathering and trace metal release by bacterial reduction in a New Caledionia Ferralsol, Biogeochemistry 53 (2001), pp. 323-340.

[13] S.J. Stemmler, S. Loyaux-Lawniczak and J. Berthelin, Effet de la teneur en eau d'un sol sur la réduction bactérienne d'oxydes de fer, C. R. Geoscience 336 (2004), pp. 1171-1179. 